\title{
Fall Frost Effects on the Essential Oil of 'Native' Spearmint (Mentha spicata L.) in Wyoming
}

\author{
Valtcho D. Zheljazkov ${ }^{1}$ \\ University of Wyoming, Sheridan Research and Extension Center, 663 \\ Wyarno Road, Sheridan, WY 82801
}

Charles L. Cantrell

U.S. Department of Agriculture, Agricultural Research Service, Natural

Products Utilization Research Unit, P.O. Box 8048, University, MS 38677

Tess Astatkie

Dalhousie University, Faculty of Agriculture, P.O. Box 550, Truro, NS, B2N 5E3, Canada

\section{Ekaterina Jeliazkova \\ University of Wyoming, Sheridan Research and Extension Center, 663 Wyarno Road, Sheridan, WY 82801}

Additional index words. Mentha spicata, harvest date, frost tolerance, essential oil content, essential oil composition, carvone

\begin{abstract}
Native' spearmint (Mentha spicata L.) is a widely grown essential oil crop worldwide and in the midwest in the United States. There is interest in expanding spearmint production to Wyoming and other states. However, there is no information to determine if spearmint would perform well under the Wyoming high-altitude and shortgrowing season and if its productivity and oil quality would be affected by fall frosts. The objective of this study was to evaluate the effect of fall frosts at the end of the cropping season on 'Native' spearmint productivity and oil profile. Spearmint plants were harvested at the following harvest dates (HDs): 14 Sept., 21 Sept., 28 Sept., 5 Oct., 12 Oct., 24 Oct., and 1 Nov. 2011. The HDs were selected to coincide with the fall frosts in northern Wyoming. Indeed, during that time, frost occurred on the following dates: 21 Sept., 10 Oct., 13 Oct., 15 Oct., 19 Oct., 20 Oct., 24 Oct., 25 Oct., 26 Oct., 27 Oct., 28 Oct., 29 Oct., 30 Oct., 31 Oct., and 1 Nov. 2011. The first heavy snow occurred on 3 Nov. Fresh herbage yields were higher at the 1 Nov. HD relative to the 14 Sept. HD, whereas the yields at the other HD were not significantly different. Generally, the oil content was high at 14 Sept., 21 Sept., and 5 Oct. HD and low at the 24 Oct. and 1 Nov. HD. Carvone concentration ( $42 \%$ to $75 \%$ range) in the oil reached a maximum at the 12 Oct. HD. The concentration of limonene was low at the first HD (14 Sept.) and higher at the other HDs. The yield of carvone (a function of the fresh herbage yields, oil content, and the concentration of carvone in the oil) was high at the 12 Oct. HD and low at the other HDs. In the spring of 2012, spearmint emerged in late April and was unaffected by the Wyoming winter or by the early spring frosts. This preliminary study suggests 'Native' spearmint may be a viable crop for northern Wyoming at elevation of $\approx 1170 \mathrm{~m}$.
\end{abstract}

'Scotch' spearmint (Mentha $\times$ gracilis Sole. $=$ M. cardiaca L. ) and 'Native' spearmint (Mentha spicata L.) are well-known and widely grown essential oil crops in many countries, including the United States

Received for publication 19 July 2012. Accepted for publication 28 Sept. 2012

This research was funded by the SunGrant Initiative Program project entitled "Development of Production Systems for Emerging Feedstock for Double Utilization" awarded to Dr. Zheljazkov.

We thank Mr. Lyn Ciampa, Ms. Lacey Fisher, Ms. Berva Brock, Ms. Michelle Box, and Mrs. Leanne Roadifer for their help with the field trials and oil extraction.

${ }^{1}$ To whom reprint requests should be addressed; e-mailvjeliazk@uwyo.edu: or valtcho.pubs@gmail. com.
(Bienvenu et al., 1999; Lawrence, 2006). The essential oils of the two spearmint species are used as aromatic agents in a number of consumer products (toothpaste, chewing gum) in food and pharmaceutical industries (Mint Industry Research Council, 2011). Previous research has demonstrated that spearmint essential oil or carvone (the major essential oil constituent) possesses antimicrobial properties (Aggarwal et al., 2002; de Carvalho and Da Fonseca, 2006; Chao et al., 2000; Kanatt et al., 2008; Rafii and Shahverdi, 2007; Rasooli et al., 2009; Sivropoulou et al., 1995; Sokovic et al., 2009).

In the United States, spearmints are grown in the Midwest and northwestern regions but not in Wyoming (National Agricultural Statistics Service, 2011). Wyoming growers expressed interest in spearmints as essential oil crops. In addition, we are currently evaluating spearmints as alternative biofuel crops for Wyoming. However, there is no previous research on spearmints in Wyoming. The Wyoming climate is different from the milder climates in the northwestern United States; the frost-free period is relatively short (120 to $125 \mathrm{~d}$ ) and the elevation is high (the elevation in Wyoming ranges from $945 \mathrm{~m}$ to $4207 \mathrm{~m}$ ). As a result of the short frost-free period and high elevation of Wyoming, one of the questions that needed to be addressed is the effect of low temperatures and early frosts on spearmint biomass yields, essential oil yield and composition. The objective of this study was to evaluate the effect of lowering temperatures and frosts naturally occurring at the end of the cropping season on spearmint productivity and oil profile.

\section{Materials and Methods}

Field experiments. In this study, we used one of the widely grown spearmints in the United States: 'Native' (Mentha spicata L.). The field experiments were established in 2011 at the Sheridan College Experimental Fields (lat. $44^{\circ} 45.686^{\prime} \mathrm{N}$, long. $-106^{\circ} 55.479^{\prime} \mathrm{W}$ ) at an elevation of $1171 \mathrm{~m}$ above sea level. We used certified virus-free planting material $(\approx 10-\mathrm{cm}$ tall plantlets with a well-established root system) of 'Native' spearmint from the Summit Plant Laboratories, Inc. (Fort Collins, $\mathrm{CO})$. This spearmint cultivar is a hybrid (Tucker, 1992; Tucker and Fairbrothers, 1990) and is propagated only vegetatively (Ellis and Stevenson, 1950; Lawrence, 2006; Tucker and Fairbrothers, 1990).

The soil was Wyarno clay loam, $\mathrm{pH} 6.8$, $1.5 \%$ organic matter content, $1.15 \mathrm{~g} \cdot \mathrm{cc}^{-1}$ bulk density, and the slope was $\approx 1 \%$. Land preparation included disking and preparation of low beds ( $12 \mathrm{~cm}$ high, $80 \mathrm{~cm}$ across) using a press-pan-type bed shaper machine. The machine also placed a drip-tape irrigation tube at 5 to $6 \mathrm{~cm}$ below the soil surface along the center of each bed. For weed control, Sinbar (Terbacil $80 \% \mathrm{WP}$ ) at $2 \mathrm{~kg} \cdot \mathrm{ha}^{-1}$ was applied on top of the beds and incorporated immediately before planting. The planting was done on 28 June 2011. Nitrogen fertilizer (33-0-0 ammonium nitrate) was surfaceapplied after transplanting at $180 \mathrm{~kg} \mathrm{~N} / \mathrm{ha}$. Spearmint was transplanted by hand in two rows on each bed, at $30 \mathrm{~cm}$ between plants in each row, and with interrow spacing of $30 \mathrm{~cm}$. Irrigation was applied once a week to provide 1 inch water/week through the drip tape (8-mil, emitters spaced at 12 inches, 0.45 GPM/100 feet).

There were no pests and disease incidence during the growing season as a result of low relative humidity. Plants were harvested by cutting with a hedge trimmer at 4 to $5 \mathrm{~cm}$ above the soil surface. HDs were 14 Sept., 21 Sept., 28 Sept., 5 Oct., 12 Oct., 24 Oct., and 1 Nov. These dates were selected based on previous weather records to coincide with the period of fall frosts in northern Wyoming. Indeed, the first snow that covered the ground completely came right after the last HD, on 
3 Nov. During that time, frost occurred on the following dates: 10 Oct. $\left(-1^{\circ} \mathrm{C}\right), 13$ Oct. $\left(-2.8^{\circ} \mathrm{C}\right), 15$ Oct. $\left(-2{ }^{\circ} \mathrm{C}\right), 19$ Oct. $\left(-4{ }^{\circ} \mathrm{C}\right)$, 20 Oct. $\left(-2.2^{\circ} \mathrm{C}\right), 24$ Oct. $\left(-1{ }^{\circ} \mathrm{C}\right), 25$ Oct. $\left(-1{ }^{\circ} \mathrm{C}\right), 26$ Oct. $\left(-7{ }^{\circ} \mathrm{C}\right), 27$ Oct. $\left(-5^{\circ} \mathrm{C}\right)$ 28 Oct. $\left(-6^{\circ} \mathrm{C}\right), 29$ Oct. $\left(-5^{\circ} \mathrm{C}\right), 30$ Oct. $\left(-6^{\circ} \mathrm{C}\right)$, 31 Oct. $\left(-3^{\circ} \mathrm{C}\right)$, and 1 Nov. $\left(-3^{\circ} \mathrm{C}\right)$ (Fig. 1$)$.

The yields of fresh herbage were taken. The essential oil was extracted from fresh samples (500 g each) through steam distillation in 2-L steam distillation units for $60 \mathrm{~min}$ as described previously (Gawde et al., 2009; Zheljazkov et al., 2010a, 2010b). The essential oils were measured on an analytical scale and kept in a freezer at $-14{ }^{\circ} \mathrm{C}$ until the analyses. The essential oil content was calculated as grams of oil per weight of fresh herbage.

Gas chromatography-flame ionization detection sample preparation and analysis. The quantitative analyses of oil samples were performed using gas chromatography-flame ionization detection (GC-FID) at the National Center for Natural Products Research in Oxford, MS, using the GC methods described in Zheljazkov et al. (2010a).

Quantitative analysis. Commercial standards $(-)$-carvone and $(R)-(+)$-limonene were obtained from Fluka (Buchs, Switzerland). With five concentration points, a least squares regression for quantification was used. Each specific analyte was used to formulate a separate calibration curve using FID response data. Linearity was imposed by using response factors (RFs) and regression coefficients independently. RFs were calculated using the equation $\mathrm{RF}=\mathrm{DR} / \mathrm{C}$, where $\mathrm{DR}$ was the detector response in peak area (PA) and $\mathrm{C}$ was the analyte concentration. The chromatograms of each of the essential oil samples from the field experiments were compared with the chromatograms from standards. Target analytes were confirmed by retention time. Confirmed integrated peaks were used to determine percentage of each chemical constituent in the essential oil itself. The RF of the target chemical constituent was used to determine the individual analyte percentage for each sample using the equation $\mathrm{PA} / \mathrm{RF} / \mathrm{C} \times 100=\%$ analyte in the oil on a wt (analyte)/wt (oil) basis.

Statistical methods. The effect of Harvest date on seven response measurements (fresh herbage yield, \% oil content from fresh herbage, fresh herbage oil yield, car- vone concentration, limonene concentration, carvone yield, and limonene yield) was determined by completing analysis of variance (ANOVA) of a completely randomized design with three replications. The levels of HD were 14 Sept. 2011, 21 Sept. 2011, 28 Sept. 2011, 5 Oct. 2011, 12 Oct. 2011, 24 Oct. 2011, and 1 Nov. 2011. For each response, the validity of model assumptions was verified by examining the residuals as described in Montgomery (2009).

The ANOVA was completed using the GLM procedure of SAS (SAS Institute Inc., 2008), and further multiple means comparison was completed for significant $(P<0.05)$ and marginally significant $(0.05<P<0.10)$ effects using Duncan's multiple range test (Montgomery, 2009). Letter groupings were generated using a $5 \%$ level of significance.

\section{Results}

The major oil constituents of 'Native' spearmint were carvone and limonene (Fig. 2). HD had significant effects on fresh oil yields $(P=0.067)$, oil content $(P=0.003)$, on the concentrations of carvone $(P=0.001)$ and limonene $(P=0.002)$ and on the yields of carvone $(P=0.001)$ and limonene $(P=0.002)$. Fresh herbage yields were higher at the 1 Nov. HD than on the 14 Sept. HD, whereas the yields at the other HD were not significantly different (Table 1). Generally, the oil content was higher at 14 Sept., 21 Sept., 5 Oct. HDs and lower at the 24 Oct. and 1 Nov. HDs.

Carvone concentration in the oil reached a maximum at the 12 Oct. HD. The concentration of limonene was low at the first HD (14 Sept.) and higher at the other HDs. The yield of carvone (a function of the fresh herbage yields, oil content, and the concentration of carvone in the oil) was highest at 12 Oct. HD. The yield of limonene was the highest at the 5 Oct. HD and the lowest at the 14 Sept. HD (Table 1). In the spring of 2012, spearmints emerged in late April and were unaffected by the early spring frosts or by the Wyoming winter.

The relationship between number of days after the first frost (14 Sept.) and fresh oil yield, oil content, and the concentration and yield of limonene was adequately described by a second-order polynomial regression model (Fig. 3). There was no definite relationship between number of days after the first frost and carvone concentration or carvone yield.

\section{Concluding Discussion}

Carvone is the major and the most important oil constituent of 'Native' spearmint as a result of its antimicrobial properties (Aggarwal et al., 2002; de Carvalho and Da Fonseca, 2006). The concentration of carvone in the oil in this study was either higher or similar to the one reported previously for the United States (Lawrence, 2006; Murray et al., 1972; Zheljazkov et al., 2010a) or elsewhere in the world (Bienvenu et al., 1999; Chowdhury et al., 2007; Kizil and Toncer, 2006; Sokovic et al., 2009). For example, in experiments with the same cultivar of spearmint, Zheljazkov et al. (2010a) reported carvone concentrations of the oil in the range of $59 \%$ to $62 \%$ at Verona, MS, and $68 \%$ to $74 \%$ at Stoneville, MS. Murray et al. (1972) in experiments with the same cultivar of spearmint in Indiana and Michigan in the 1970s reported carvone concentration range of $58 \%$ to $68 \%$. In experiments conducted outside the United States, Chowdhury et al. (2007) reported a carvone concentration of $73 \%$ in M. spicata in India; Bienvenu et al. (1999) reported carvone concentrations range of $68 \%$ to $72 \%$ in 'Native' spearmint at two locations and $62 \%$ for another location in Australia.

Cold-hardiness (frost resistance) of spearmints is an important trait, allowing for wider distribution and adaptation. Hence, breeding programs have been underway for many years on improving cold-hardiness of spearmints in Bulgaria (Georgiev, 1989), India (Patra et al., 2000), Russia (Bugaenko et al., 1975; Popovich et al., 1978), and Ukraine (Shelud'ko, 1990). This report is the first demonstrating that 'Native' spearmint could be harvested after the first few frosts and provides good yields and quality. Also, this report is the first one on spearmints in Wyoming.

Although fresh herbage yields at the 1 Nov. HD increased, the oil content at 1 Nov. HD was lower than at the 14 Sept. HD. Carvone concentration and yield reached maximum at the 12 Oct. HD, indicating that 'Native' spearmint could be harvested after

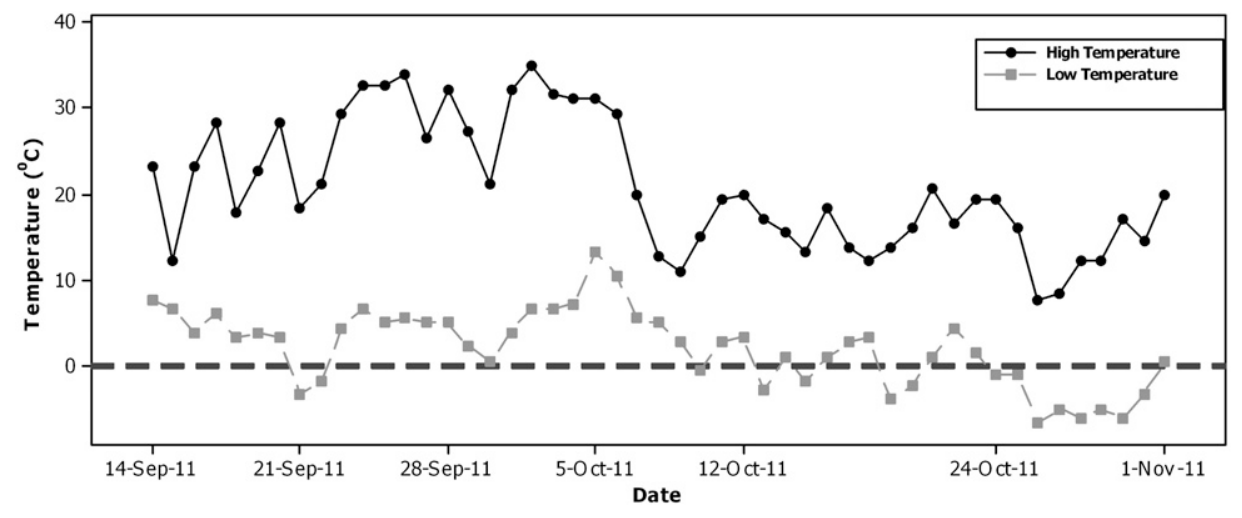

Fig. 1. Temperature from 14 Sept. 2011 to 1 Nov. 2011 at Sheridan, WY. 


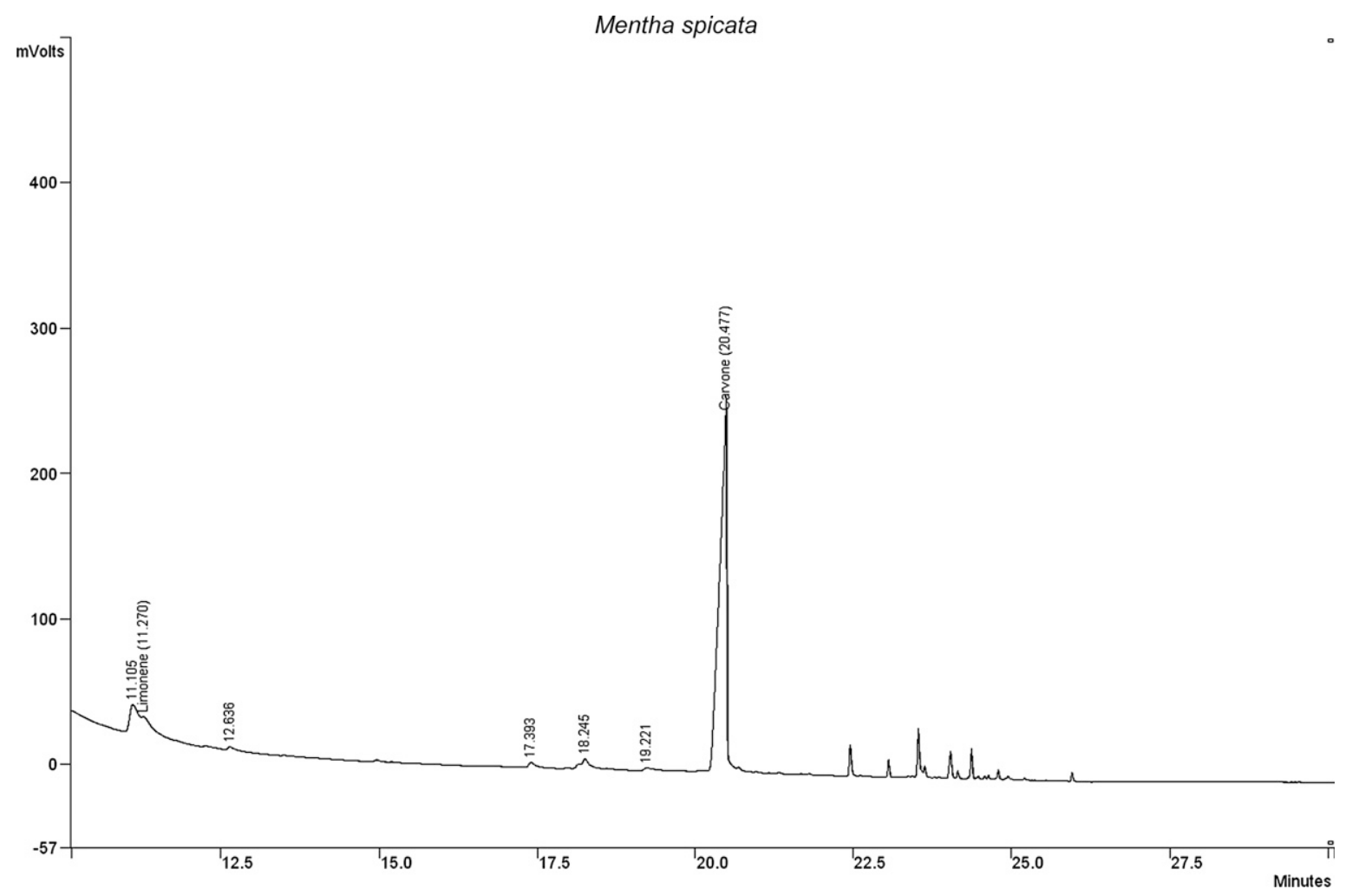

Fig. 2. Representative gas chromatography-flame ionization detection chromatogram of Mentha spicata 'Native'.

Table 1. Mean fresh yield $\left(\mathrm{kg} \cdot \mathrm{ha}^{-1}\right)$, oil content $(\%)$, carvone concentration (\%), limonene concentration (\%), carvone yield $\left(\mathrm{kg} \cdot \mathrm{ha}^{-1}\right)$, and limonene yield $\left(\mathrm{kg} \cdot \mathrm{ha}^{-1}\right)$ from the seven harvest dates.

\begin{tabular}{|c|c|c|c|c|c|c|}
\hline Harvest date & $\begin{array}{c}\text { Fresh } \\
\text { yield }\left(\mathrm{kg} \cdot \mathrm{ha}^{-1}\right)\end{array}$ & $\begin{array}{c}\text { Oil } \\
\text { content }(\%)\end{array}$ & $\begin{array}{l}\text { Carvone } \\
\text { concn }(\%)\end{array}$ & $\begin{array}{l}\text { Limonene } \\
\text { concn (\%) }\end{array}$ & $\begin{array}{c}\text { Carvone } \\
\text { yield }\left(\mathrm{kg} \cdot \mathrm{ha}^{-1}\right)\end{array}$ & $\begin{array}{c}\text { Limonene } \\
\text { yield }\left(\mathrm{kg} \cdot \mathrm{ha}^{-1}\right)\end{array}$ \\
\hline 14 Sept. 2011 & $9001 \mathrm{~b}^{\mathrm{z}}$ & $0.216 \mathrm{a}$ & $58.5 \mathrm{~b}$ & $2.40 \mathrm{~b}$ & $11.2 \mathrm{~b}$ & $0.50 \mathrm{c}$ \\
\hline 21 Sept. 2011 & $11445 \mathrm{ab}$ & $0.205 \mathrm{a}$ & $54.6 \mathrm{~b}$ & $4.25 \mathrm{a}$ & $13.2 \mathrm{~b}$ & $1.12 \mathrm{ab}$ \\
\hline 28 Sept. 2011 & $10853 \mathrm{ab}$ & $0.194 \mathrm{ab}$ & $42.4 \mathrm{c}$ & $4.81 \mathrm{a}$ & $8.9 \mathrm{~b}$ & $1.01 \mathrm{ab}$ \\
\hline 5 Oct. 2011 & $12964 \mathrm{ab}$ & $0.200 \mathrm{a}$ & $42.9 \mathrm{c}$ & $4.69 \mathrm{a}$ & $11.1 \mathrm{~b}$ & $1.22 \mathrm{a}$ \\
\hline 12 Oct. 2011 & $12927 \mathrm{ab}$ & $0.203 \mathrm{a}$ & $74.6 \mathrm{a}$ & $4.38 \mathrm{a}$ & $19.4 \mathrm{a}$ & $1.12 \mathrm{ab}$ \\
\hline 24 Oct. 2011 & $14890 \mathrm{ab}$ & $0.140 b c$ & $56.5 \mathrm{~b}$ & $3.77 \mathrm{a}$ & $11.6 \mathrm{~b}$ & $0.78 \mathrm{bc}$ \\
\hline 1 Nov. 2011 & $15909 \mathrm{a}$ & $0.137 \mathrm{c}$ & $44.6 \mathrm{c}$ & $3.85 \mathrm{a}$ & $9.6 \mathrm{~b}$ & $0.82 \mathrm{bc}$ \\
\hline
\end{tabular}

${ }^{\mathrm{z}}$ Means followed by the same letter are not significantly different at the $5 \%$ level of significance.

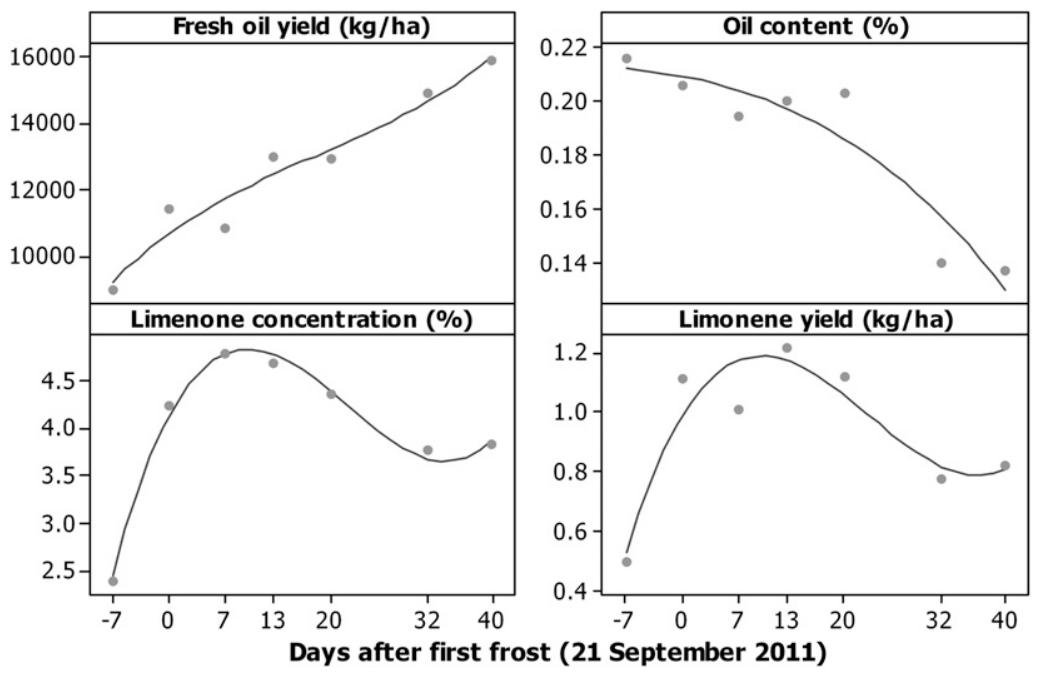

Fig. 3. Plot of number of days after the first frost vs. fresh oil yield, oil content, limonene concentration, and limonene yield together with fitted third order (cubic) polynomial regression model. the first few frosts and provide good oil yields and quality. The early development of spearmints in 2012, along with the demonstrated cold-hardiness early in the spring and in late fall, may suggest possibility for two consecutive cuts within a single cropping season in northern Wyoming. A second cut may improve the overall economics and the spearmint prospective to be used as an alternative biofuel crop. This preliminary study suggests 'Native' spearmint may be a viable crop for northern Wyoming.

\section{Literature Cited}

Aggarwal, K.K., S.P.S. Khanuja, A. Ateeque, T.R.S. Kumar, V.K. Gupta, and S. Kumar. 2002. Antimicrobial activity profiles of the two enantiomers of limonene and carvone isolated from the oils of Mentha spicata and Anethum sowa. Flavour Frag. J. 17:59-63.

Bienvenu, F., L. Peterson, and J. Edwards. 1999. Native and Scotch spearmint oil production in Tasmania and Victoria. A report for Rural Industries Research and Development Corporation. Publ. \#99/147, Project \#DAV-101A, p. 32. 28 Sept. 2012. $<$ https://rirdc.infoservices. com.au/downloads/99-147>.

Bugaenko, L.A., S.A. Reznikova, and A.L. Popovich 1975. The method of interspecific hybridization in breeding peppermint. Trudy po Prikladnoi Botanike. Genetike i Selektsii. 54:267272.

Chao, S.C., D.G. Young, and C.J. Oberg. 2000 Screening for inhibitory activity of essential oils on selected bacteria, fungi and viruses. J. Essent. Oil Res. 12:639-649.

Chowdhury, J.U., N.C. Nandi, M. Uddin, and M. Rahman. 2007. Chemical constituents of 
essential oils from two types of spearmint (Mentha spicata L. and M. cardiaca L.) introduced in Bangladesh. Bangl. J. Sci. Indus. Res. 42:79-82.

de Carvalho, C.C.C.R. and M.M.R. Da Fonseca. 2006. Carvone: Why and how should one bother to produce this terpene. Food Chem. 95:413-422.

Ellis, N.K. and E.C. Stevenson. 1950. Domestic production of essential oils of peppermint and spearmint. Econ. Bot. 4:139-149.

Gawde, A.J., C.L. Cantrell, and V.D. Zheljazkov. 2009. Dual extraction for secondary metabolites from Juniperus virginiana. Ind. Crops Prod. 30:276-280.

Georgiev, S. 1989. Mechta spearmint. Zemedelie. 87:51-52.

Kanatt, S.R., R. Chander, and A. Sharma. 2008 Chitosan and mint mixture: A new preservative for meat and meat products. Food Chem. 107:842-852.

Kizil, S. and O. Toncer. 2006. Influence of different harvesting times on the yield and oil composition of spearmint (Mentha spicata L. var. spicata). J. Food Agr. Environ. 4:135-137.

Lawrence, B.M. 2006. Mint: The genus Mentha. CRC Press, Boca Raton, FL.

Mint Industry Research Council. 2011. June 2011. $<$ http://usmintindustry.org/Home/tabid/53/Default. aspx $>$.

Montgomery, D.C. 2009. Design and analysis of experiments. $7^{\text {th }}$ Ed. Wiley, New York, NY.
Murray, M.J., W. Faas, and P. Marble. 1972. Effects of plant maturity on oil composition of several spearmint species grown in Indiana and Michigan. Crop Sci. 12:723-728.

NASS (National Agricultural Statistics Service). 2011. Crop values. 2011 Summary. February 2012. 31 Mar. 2012. <http://usda01.library.cornell. edu/usda/current/CropValuSu/CropValuSu-0216-2012.pdf>.

Patra, N.K., S.P.S. Khanuja, A.K. Shasany, H.P. Singh, V.R. Singh, H. Tanveer, A. Kalra, H.B. Singh, N. Mengi, N.K. Tyagi, A.A. Naqvi, and S. Kumar. 2000. Genetic improvement of cultivated species of Cymbopogon and Mentha for yield, quality and adaptation. J. Med. Arom. Plant Sci. 22:263-277.

Popovich, A.L., L.A. Bugaenko, and S.A. Reznikova. 1978. Breeding a new winter-hardy variety of mint by means of interspecific hybridization. Trudy VNII efiromaslichnih kultur. 11: 11-17.

Rafii, F. and A.R. Shahverdi. 2007. Comparison of essential oils from three plants for enhancement of antimicrobial activity of nitrofurantoin against enterobacteria. Chemotherapia (Basel) 53:21-25.

Rasooli, I., S. Shayegh, and S.D.A. Astaneh. 2009. The effect of Mentha spicata and Eucalyptus camaldulensis essential oils on dental biofilm. J. Dent. Hyg. 1-8. doi: 10.1111/j.1601-5037. 2009.00389 .
SAS Institute Inc. 2008. SAS/STAT ${ }^{\circledR} 9.2$ user's guide. SAS Institute Inc., Cary, NC.

Shelud'ko, L.A. 1990. Results of work on the introduction of mint species in the forest steppe of the Ukraine and their use in breeding. Tezisy dokladov i soobshchenii Vsesoyuznoi konferentsii, 28 Oct. to 1 Nov. 1990. Moscow, Russia. p. 73-74.

Sivropoulou, A., S. Kokkini, T. Lanaras, and M. Arsenakis. 1995. Antimicrobial activity of mint essential oils. J. Agr. Food Chem. 43:2384-2388.

Sokovic, M.D., J. Vukojevic, P.D. Marin, D.D Brkic, V. Vajs, and L.J.L.D. van Griensven. 2009. Chemical composition of essential oils of Thymus and Mentha species and their antifungal activities. Molecules 14:238-249.

Tucker, A.O. 1992. The truth about mints. Herb Companion. 4:51-52.

Tucker, A.O. and D.E. Fairbrothers. 1990. The origin of Mentha $\times$ gracilis (Lamiaceae). I. Chromosome numbers, fertility, and three morphological characters. Econ. Bot. 44:183-213.

Zheljazkov, V.D., C.L. Cantrell, T. Astatkie, and M.W. Ebelhar. 2010a. Productivity, oil content and composition of two spearmint species in Mississippi. Agron. J. 102:129-133.

Zheljazkov, V.D., C.L. Cantrell, T. Astatkie, and A. Hristov. 2010b. Yield, content, and composition of peppermint and spearmints as a function of harvesting time and drying. J. Agr. Food Chem. 58:11400-11407. 